\title{
A clinicopathological study of dysfunctional uterine bleeding
}

\author{
Katuwal $N^{1}$, Gurung $\mathrm{G}^{1}$, Rana $\mathrm{A}^{1}$, Jha $\mathrm{A}^{2}$ \\ ${ }^{I}$ Department of Obstetrics and Gynaecology, Tribhuvan University Teaching Hospital, Kathmandu, Nepal. \\ ${ }^{2}$ Department of Pathology, Tribhuvan University Teaching Hospital, Kathmandu, Nepal.
}

\section{Keywords: \\ Uterine bleeding; Endometrial Biopsy; Histopathology.}

\begin{abstract}
Background: Dysfunctional uterine bleeding is a form of abnormal uterine bleeding when there is absence of organic disease of the genital tract. The objective of this study was to find out the clinical and pathological aspect of women presenting with dysfunctional uterine bleeding.

Materials and Methods: A descriptive study was conducted over a period of one year from April 14th 2010 to April 13th 2011 in the Department of Obstetrics and Gynaecology and Department of Pathology, Tribhuvan University Teaching Hospital, Kathmandu, Nepal. A complete history, clinical examination, pelvic scan, hormonal status if required and endometrial biopsy were done to diagnose dysfunctional uterine bleeding.

Results: A total of 120 cases were included. The age of the patients diagnosed dysfunctional uterine bleeding were ranging from $24-63$ years. Dysfunctional uterine bleeding was most common in the age group 40-44 yrs (30\%) followed by $45-49$ yrs $(27.5 \%)$. Menorrhagia $(41.7 \%)$ was the most common presenting sign. Majority histopathology of endometrium revealed anovulatory pattern $(61.7 \%)$ followed by ovulatory $(38.3 \%)$. Of the cases with an anovulatory pattern $48.6 \%$ was proliferative endometrium, $33.8 \%$ disordered proliferative endometrium, $6.8 \%$ atrophic, $5.4 \%$ weakly proliferative and $2.7 \%$ each of simple hyperplasia without atypia and complex hyperplasia with atypia. All cases with ovulatory pattern showed secretory endometrium.
\end{abstract}

Conclusion: Dysfunctional uterine bleeding was the most common in the perimenopausal age group and chiefly in the form of an anovulatory endometrium. . Histopathological evaluation of endometrium helps exclude the local causes and establishes the diagnosis of dysfunctional uterine bleeding, its types, and clinical correlation to histopathological findings and finally helps to determine the mode of management.

\section{INTRODUCTION}

In normal menstruation, cycle length is $21-35$ days, duration of menstrual blood flow is 2-7 days and blood

\section{Correspondence:}

Dr Neeta Katuwal, MD

Department of Obstetrics and Gynaecology

Tribhuvan University Teaching Hospital, Kathmandu, Nepal.

Email:neetakums@hotmail.com loss is $20-80 \mathrm{ml} .{ }^{1}$ Any deviation from this normal pattern is recognized as abnormal. Any vaginal bleeding is abnormal in postmenopausal women. ${ }^{2,3}$ In UK, Abnromal uterine bleeding (AUB) accounts for 5\% of referrals to General Practitioner's and $12 \%$ of all new gynecological referrals. ${ }^{4}$

AUB can also be categorized into two broad groups first is due to organic causes, having some pathology like fibroid, 
polyp etc and the second is the so called dysfunctional uterine bleeding (DUB) when there is absence of organic disease of the genital tract' or, in words of Novak et al. 'abnormal bleeding from the uterus unassociated with tumor, inflammation or pregnancy'.5,6

DUB can be classified into primary, secondary and iatrogenic groups. ${ }^{6}$ Primary DUB is due to dysfunction arising in the hypothalamo-pitutary -ovarian axis or dysfunction in the endometrium itself. Secondary DUB is due to endocrinopathies, hematological, vascular disease, liver disorders. Iatrogenic DUB is caused by drugs, exogenous hormone administration, intrauterine contraceptive devices. It is a diagnosis of exclusion; and one should proceed through logical stepwise evaluation to rule out all other causes of abnormal uterine bleeding.

DUB maybeassociated with almostany type ofendometrium, even apparently normal endometrium like proliferative and secretory. Some other histology of endometrium in DUB are disordered proliferative, hyperplasia, irregular ripening, irregular shedding, atrophy. ${ }^{6-8}$ This study aims to find clinical and pathological aspect of women presenting with DUB.

\section{MATERIALS AND METHODS}

A descriptive study was conducted over a period of one year from April 14 2010 to April 13 $3^{\text {th }} 2011$ in the Department of Obstetrics and Gynaecology and Department of Pathology, Tribhuvan University Teaching Hospital Maharajgunj, Kathmandu, Nepal. Patients attending the Gynecological outpatient department with abnormal uterine bleeding were included in the study. Adolescent age was not included in the present study as endometrial sampling is not the primary diagnostic tool for this age group. A complete history, clinical examination, pelvic scan and hormonal status and endometrial biopsy were done to diagnose DUB.

Endometrial biopsy was performed by the researcher using Karman cannula in OPD basis. Time of endometrial biopsy was taken after 15 days from the last menstrual period (preferably Day 21-22) so that hormonal status could be determined in addition to pathology. Women who were bleeding were put on non-hormonal methods of treatment till the procedure was awaited. Endometrial tissue obtained was immediately kept in $10 \%$ formalin and sent to Pathology Department, TUTH. In the labratory, paraffin embedded tissue sections were made, stained with Hematoxylin and Eosin and studied under microscope by pathologist.

A total of 145 clinically considered cases of DUB were subjected to endometrial biopsy. Out of these endometrial biopsies revealing organic causes (10 cases) and those samples inadequate for opinion (15 cases) were excluded. Thus total of 120 cases of DUB was included in the analysis.

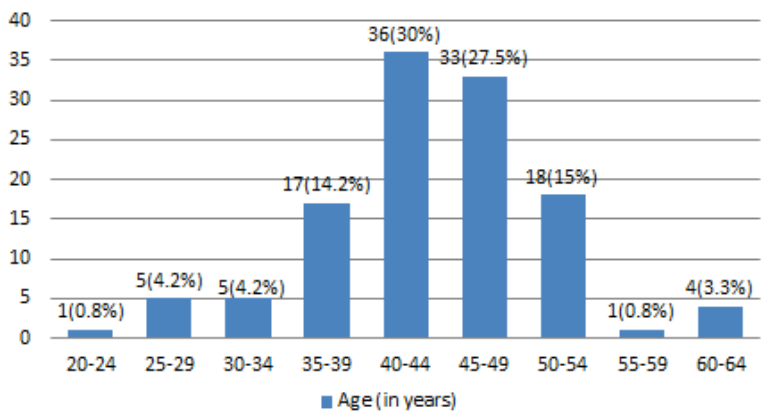

Figure 1. Distribution of women by age (in years)

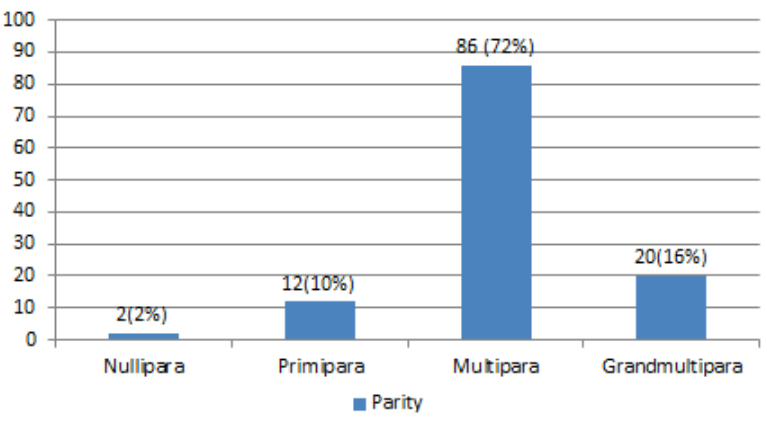

Figure 2: Distribution of women according to parity

The data were analysed using Stastical Package for Social Studies (SPSS) version 18.

\section{RESULTS}

The age of the patients diagnosed DUB were ranging from $24-63$ years. DUB was most common in the age group 40$44 \mathrm{yrs}(30 \%)$. (fig. 1) It was more common in parous than in nulliparous women. (fig. 2)

The most common menstrual disorder in women presenting with DUB was menorrhagia $50(41.7 \%)$, followed by menometrorrhagia 47 (39.2\%), metrorrhagia 7 (5.8\%), polymenorrhea $4(3.3 \%)$, polymenorrhagia $3(2.5 \%)$ and $9(7.5 \%)$ women presented with postmenopausal bleeding. (Table 1) Among the 120 women with DUB, majority 74 $(61.7 \%)$ had anovulatory pattern of endometrium. Ovulatory pattern was detected in 46 (38.3\%).

In both reproductive and perimenopausal age group DUB was most commonly associated with anovulatory pattern of endometrium. All postmenopausal women with DUB had anovulatory pattern. (Table 2) The most common endometrial histology in anovulatory DUB was proliferative $36(48.6 \%)$ followed by disordered proliferative $25(33.8 \%)$, atrophic endometrium $5(6.8 \%)$, weakly proliferative 4 


\section{Table 1: Menstrual disorders in women with DUB}

\begin{tabular}{lc}
\hline Menstrual disorder & Number (\%) \\
\hline Menorrhagia & $50(41.6 \%)$ \\
Menometrorrhagia & $47(39.2 \%)$ \\
Metrorrhagia & $7(5.8 \%)$ \\
Polymenorrhoea & $4(3.3 \%)$ \\
Polymenorrhagia & $3(2.5 \%)$ \\
Postmenopausal bleeding & $9(7.5 \%)$ \\
\hline Total & $\mathbf{1 2 0}(\mathbf{1 0 0} \%)$ \\
\hline
\end{tabular}

(5.4\%), simple hyperplasia without atypia and complex atypical hyperplasia of $2(2.7 \%)$ each. All cases of ovulatory DUB had secretory endometrium. (Table 3 )

\section{DISCUSSION}

AUB is a common gynecological condition. Evaluation of patient with abnormal uterine bleeding and identifying those with DUB is achieved with the combination of the following: history, physical examination, laboratory evaluation, USG and confirmed by endometrial sampling.

The present study showed DUB, most common in the age group 40-44 years, accounting for $30 \%$ followed by $27.5 \%$ in 45-49 years age group. Present study findings were comparable to studies done by Muzaffar et $\mathrm{al}^{9}$ and Thanyapa W10 who reported menstrual disorders to be common in age group 41-50 years. common menstrual disorder in women presenting with DUB accounting for $41.6 \%$ of cases followed by menometrorrhagia of $39.2 \%$ and metrorrhagia $7 \%$ which was less compared to $51.9 \%$ of cases of menorrhagia and $35.4 \%$ metrorrhagia mentioned by Muzaffar $\mathrm{M}$ et al. ${ }^{9}$ Also study by Bhosle A et $\mathrm{al}^{11}$ showed menorrhagia as major clinical symptom in perimenopausal women with abnormal uterine bleeding. There were 9 cases $(7.5 \%)$ in the present study with postmenopausal DUB which was comparable $9.2 \%$ cases in study by Thanyapa W10, $8.6 \%$ by Ha BS et al. ${ }^{12}$ In a study by Dangal $\mathrm{G}^{13}$ where peri and postmenopausal women were included, there were higher percentage $(53.5 \%)$ cases of postmenopausal bleeding.

In the absence of ovulation and the production of progesterone, endometrium responds to excessive or unopposed estrogen stimulation with proliferation and this over time may induce hyperplastic response in the proliferating endometrium. ${ }^{5,6}$ In present study most common histology of endometrium in anovulatory DUB was proliferative 48.6 percent. Similar results of proliferative endometrium as the most common pattern was obtained in the study in study by Ha BS et al ${ }^{12}$ of $99 \%$, that by Hoon CN et $\mathrm{al}^{14}$ of $50.85 \%$, Somboonporn W et al. ${ }^{15}$ of $75 \%$, Muzaffar $\mathrm{M}$ et al. ${ }^{9}$ of $27.4 \%$ and also by other studies. ${ }^{10,11,16,17}$ The second common endometrial histology in anoulatory DUB in present study was Disordered proliferative endometrium 33.8 percent. This type of endometrial histology was also seen in the study by Hoon $\mathrm{CN}$ et al..$^{14}$ of $49 \%$, Vakiani M et $\mathrm{a}^{18}$ of $41.86 \%$ and Baral R, Pudasaini S of 10 percent. ${ }^{19}$

The present study showed menorrhagia as the most Atrophic endometrium as a type of anovulatory pattern

Table 2: Histopathological findings of endometrium in DUB and its distribution in adult reproductive, perimenopausal and postmenopausal age group.

\begin{tabular}{|c|c|c|c|c|}
\hline \multirow[b]{2}{*}{ HPE } & \multicolumn{3}{|c|}{ Age Group } & \multirow[b]{2}{*}{ Total } \\
\hline & $\begin{array}{c}20-40 \text { years } \\
\text { Adult Reproductive } \\
(\mathrm{n}=38)\end{array}$ & $\begin{array}{c}>40 \text { years } \\
\text { Perimenopausal } \\
(n=73)\end{array}$ & $\begin{array}{c}\text { Post menopausal } \\
\qquad(\mathrm{n}=9)\end{array}$ & \\
\hline ANOVULATORY DUB & & & & $0(0 \%)$ \\
\hline Proliferative endometrium & $13(34.2 \%)$ & $20(27.3 \%)$ & $3(33.3 \%)$ & $36(48.6 \%)$ \\
\hline Disordered Proliferative & $6(15.7 \%)$ & $19(26 \%)$ & 0 & $25(33.8 \%)$ \\
\hline Atrophic endometrium & 0 & $1(1.3 \%)$ & $4(44.4 \%)$ & $5(6.8 \%)$ \\
\hline Weakly proliferative & $1(2.6 \%)$ & $1(1.3 \%)$ & $2(22.2 \%)$ & $4(5.4 \%)$ \\
\hline $\begin{array}{l}\text { Simple hyperplasia without } \\
\text { atypia }\end{array}$ & 0 & $2(2.7 \%)$ & 0 & $2(2.7 \%)$ \\
\hline $\begin{array}{l}\text { Complex hyperplasia with } \\
\text { atypia }\end{array}$ & 0 & $2(2.7 \%)$ & 0 & $2(2.7 \%)$ \\
\hline Total & $20(52.6 \%)$ & $45(61.6 \%)$ & $9(100 \%)$ & \\
\hline \multicolumn{5}{|l|}{ OVULATORY DUB } \\
\hline Secretory & $18(47.3 \%)$ & $28(38.3 \%)$ & 0 & $46(100 \%)$ \\
\hline Total & $18(47.3 \%)$ & $28(38.3 \%)$ & $\mathbf{0}$ & \\
\hline
\end{tabular}


was seen in $6.8 \%$ cases in the present study. Atrophic endometrium was seen mostly in the postmenopausal followed by perimenopausal women and was not seen in reproductive age group. Higher incidence atrophic endometrium of $17 \%$ by Ejaz S et $\mathrm{al}^{20}$ is due to inclusion of only postmenopausal cases and $34.5 \%$ by Dangal $\mathrm{G}^{13}$ due to inclusion of perimenopausal and postmenopausal DUB excluding reproductive age group.

In the present study endometrial pathology as hyperplasia was seen only in perimenopausal women not in reproductive or post-menopausal age group which is similar to study by Dangal G. ${ }^{13}$

DUB also develops when ovulation occurs but corpus luteum function is insufficient leading to irregular ripening of endometrium (luteal phase defect) or there may be abnormal persistence of corpus luteum leading to irregular shedding. ${ }^{5,6}$ Secretory bleeding pattern in ovulatoty DUB may be described when there is bleeding present in secretory but non menstrual background

Ovulatory DUB was associated with only secretory endometrium and accounted $35.3 \%$ of the cases in the present study. However in addition to secretory endometrium in ovulatory DUB, study by Patel BS, Delvadia JL, Desai DA15 showed irregular ripening, Vakiani $\mathrm{M}$ et al. ${ }^{18}$ showed corpus luteum defect $(15.4 \%)$, study by Hoon $\mathrm{CN}$ et al ${ }^{14}$ showed abnormal secretory type $(0.3 \%)$ and that by Ha BS et $\mathrm{a}^{12}$ showed irregular shedding (1.2\%).

\section{CONCLUSION}

The present study showed DUB most common in perimenopausal age group ( $>40$ years). Anovulatory pattern is observed in majority of cases. Histopathological evaluation of endometrium helps exclude the local causes and establishes the diagnosis of DUB, its types, clinical correlation to histopathological findings and finally helps to determine the mode of management.

Acknowledgements: I deeply appreciate the cooperation of all the women enrolled in the study.

\section{REFERENCES}

1. Algotar KM, Nalawade A. Physiology of menstruation. In: Purandare $\mathrm{CN}$ editor: Dysfunctional uterine bleeding -An update. JAYPEE: New Delhi; 2004. pp 1-15. http://dx.doi.org/10.5005/jp/books/10246_1 http://dx.doi.org/10.5005/jp/books/10246_1 Crossref

2. Kumar P, Malhotra N, editors. Menopause. Jeffcoate's Principal of Gynecology, 7th ed. New Delhi: JAYPEE;2008. 862-4pp.

3. Rock J, Jones H, editors. Normal and abnormal uterine bleeding. Te Linde's Operative Gynecology.10th ed. Philadelphia: Lippincort Williams \&Wilkins; 2009.585-92pp.

4. Bradlow J, Coulter A, Brooks P. Outcomes of referrals to gynecology outpatient clinic for menstrual problem.Br J Obstet Gynecol 1991;98:789-96. Crossref

5. Kumar P, Malhotra N, editors. Abnormal and excessive uterine bleeding. Jeffcoate's Principal of Gynecology. 7th ed. New Delhi: JAYPEE;2008. 598-616pp. PMid:18810540

6. Davey DA. Dysfunctional uterine bleeding. In: Whitfield CR editor: Dewhurst's textbook of Obstetrics and Gynecology for postgraduates. 4th ed. London: Blackwell science; 1995.pp 624-45.

7. Mills SE, Carter D, Greenson JK, Reuter VE, Stoler MH, editor. The uterine corpus. Sternberg's Diagnostic Surgical Pathology, 5thed. Vol.2.Philadelphia:Lippincort Williams \&Willkins;2010. 2190213pp.

8. Khadilkar S. Endometrium in DUB. In: Purandare CN editor: Dysfunctionaluterine bleeding-An update. New Delhi:JAYPEE;2004. pp 271-41 Crossref

9. Muzaffar M, Akhtar K, Yasmin S, Rehman M, Iqbal W, Khan M. Menstrual irregularities with excessive blood loss: a ClinicoPathological correlation. J Pak Med Assoc 2005;55:1-4. PMID:16304868

10. Thanyapa W. Histopahological result of fractional curettage in Satuk Hospital. Medical Journal of Srisaket Surin Buriram Hospital 2010; 25:93-100. Crossref

11. Bhosle A, Fonseca M. Evaluation and histopathological correlation of Abnormal uterine bleeding in Perimenopausal women. Bombay Hospital J 2010;52:69-72.

12. Ha BS, Jeung JG, Kang SH, Kim C, Chi CH. Clinical and Pathological study of Dysfunctional uterine bleeding. Korean Medical J 1993;36:847-53

13. Dangal G.A study of endometrium of patients with abnormal uterine bleeding at Chitwan valley. Kathmandu University Medical J 2003;1:110-2.

14. Hoon CN, Chan P, Joon CI. Clinicopathological study of the endometrium of Dysfunctional uterine bleeding. The Korean J of Pathology 1989;23:65-74.

15. Somboonporn W, Seejorn K, Paojirasinchai S, Puntase S. Comparison between Karman cannula and uterine curette in uterine curettage. Srinagarind Medical J 2000;151:18-22

16. Patel BS, Delvadia JL, Desai DA. Clinico-pathological \& endocrinological co-relation in cases of menstrual disturbances. [cited on 2011 August 15]:Available from SMT_NHL Municipal Medical College.mht.

17. Shaheen S, Akhtar S, Utman N. Causes of menorrhagia and its pathological diagnosis by Dilatation and Curettage. JPMI 2005; 19:62-6.

18. Vaikiani M,Vavilis D, Agorastos T, Stamatopoulos P, Assimaki A, Bontis J. Histopathological findings of the endometrium in patients with dysfunctional uterine bleeding. Clin Exp Obstet Gynecol 1996;23:236-9.

19. Baral R and Pudasaini S. Histopathological pattern of endometrial samples in abnormal uterine bleeding. $\mathrm{J}$ of Pathology of Nepal 2011;1:13-6. http://dx.doi.org/10.3126/jpn.v1i1.4443

20. Ejaz S, Zafar H, Waheed K. Causes of Postmenopausal bleeding according to histopathological findings.[cited on 2011 August 15]:42-44. Crossref 